\title{
Effect of iron oxide and gold nanoparticles on bacterial growth leading towards biological application
}

\author{
Saptarshi Chatterjee, Arghya Bandyopadhyay and Keka Sarkar
}

\begin{abstract}
Background: Nanoparticle-metal oxide and gold represents a new class of important materials that are increasingly being developed for use in research and health related activities. The biological system being extremely critical requires the fundamental understanding on the influence of inorganic nanoparticles on cellular growth and functions. Our study was aimed to find out the effect of iron oxide $\left(\mathrm{Fe}_{3} \mathrm{O}_{4}\right)$, gold $(\mathrm{Au})$ nanoparticles on cellular growth of Escherichia coli (E. coli) and also try to channelize the obtained result by functionalizing the Au nanoparticle for further biological applications.

Result: $\mathrm{Fe}_{3} \mathrm{O}_{4}$ and $\mathrm{Au}$ nanoparticles were prepared and characterized using Transmission electron microscopy (TEM) and Dynamic Light Scattering (DLS). Preliminary growth analysis data suggest that the nanoparticles of iron oxide have an inhibitory effect on E. coli in a concentration dependant manner, whereas the gold nanoparticle directly showed no such activity. However the phase contrast microscopic study clearly demonstrated that the effect of both $\mathrm{Fe}_{3} \mathrm{O}_{4}$ and $\mathrm{Au}$ nanoparticle extended up to the level of cell division which was evident as the abrupt increase in bacterial cell length. The incorporation of gold nanoparticle by bacterial cell was also observed during microscopic analysis based on which glutathione functionalized gold nanoparticle was prepared and used as a vector for plasmid DNA transport within bacterial cell.

Conclusion: Altogether the study suggests that there is metal nanoparticle-bacteria interaction at the cellular level that can be utilized for beneficial biological application but significantly it also posses potential to produce ecotoxicity, challenging the ecofriendly nature of nanoparticles.
\end{abstract}

Keywords: Bacterial Growth, magnetic nanoparticle, gold nanoparticle, Cytotoxicity

\section{Background}

The present era belongs to nanotechnology. With the tremendous growth in the field of science, nanobiotechnology has come up as a major interdisciplinary subject. The development and application of nanotechnology has the potential to improve greatly the quality of life. An improved understanding of nanoparticles and biological cell interaction can lead to the development of new sensing, diagnostic and treatment capabilities [1-4] such as improved targeted drug delivery, gene therapy, magnetic resonance imaging contrast agents and biological warfare agent detection [5,6]. For instance iron oxide nanoparticle has been widely used as carriers for targeted

\footnotetext{
* Correspondence: keka@klyuniv.ac.in

Department of Microbiology, University of Kalyani, Nadia, West Bengal, India
}

drug delivery to treat several types of cancer $[7,8]$ in biomedical research because of its biocompatibility and magnetic properties $[9,10]$. Gold nanoparticle is the other mostly applied nanoparticle in the field of biomedical sciences expanding from immunoassay [11] to in vivo cancer targeting and imaging [12].

Though there are immense potentials of nanotechnology, the cytotoxicity of the nanoparticles remain a major concern. Different classes of bacteria exhibit different susceptibilities to nanoparticles [13] but the mechanism controlling the toxicity is not yet understood. Moreover different factors such as synthesis, shape, size, composition, addition of stabilizer etc can lead to different conclusions even for very closely related nanosuspensions [14]. Thus the present study is aimed to investigate the
() Biomed Central

(ㄷ) 2011 Chatterjee et al; licensee BioMed Central Ltd. This is an Open Access article distributed under the terms of the Creative Commons Attribution License (http://creativecommons.org/licenses/by/2.0), which permits unrestricted use, distribution, and reproduction in any medium, provided the original work is properly cited. 
effect of two widely used nanoparticles $\left(\mathrm{Fe}_{3} \mathrm{O}_{4} \& \mathrm{Au}\right)$ on the growth of $E$. coli. The growth study was followed by microscopic study for detecting the morphological changes. Finally, attempts were made to utilize the results obtained for biological applications.

\section{Result and Discussion}

\section{A) Characterization of nanoparticles}

The nanoparticles (iron oxide \& gold) synthesized in the laboratory were characterized using TEM image (FEI, Tecnai S-twin) and DLS (Malvern Zetasizer). The size of magnetic nanoparticle was found to be $8 \mathrm{~nm}$ by TEM image whereas Gold nanoparticle possessed size of $5 \mathrm{~nm}$ (Figure 1, 2). The DLS data of $\mathrm{Fe}_{3} \mathrm{O}_{4}$ and Au nanoparticles as shown in Figure 3, 4. indicated monodispersity.

\section{B) Effect of Iron nanoparticle on bacterial growth}

The comparative study on growth of bacteria under normal condition and under the influence of Magnetic nanoparticle $\left(\mathrm{Fe}_{3} \mathrm{O}_{4}\right)$ revealed the effect of Fe nanoparticle on bacterial growth. The growth curve of E. coli under normal conditions clearly depicted the lag, log, stationary and death phase as shown in Figure 5 but under the influence of various concentrations of iron oxide nanoparticles (i.e $50 \mu \mathrm{g} / \mathrm{mL}, 100 \mu \mathrm{g} / \mathrm{mL}, 150 \mu \mathrm{g} /$ $\mathrm{mL} \& 200 \mu \mathrm{g} / \mathrm{mL}$ ) the gradual shortening of log phase was evident indicating the microbiostatic effect of iron nanoparticle on $E$. coli in a concentration dependant manner. The untreated bacterial sample at 6th hour reached OD600 1.48 (cfu count $1.32 \times 10^{9}$ per $\mathrm{mL}$ )

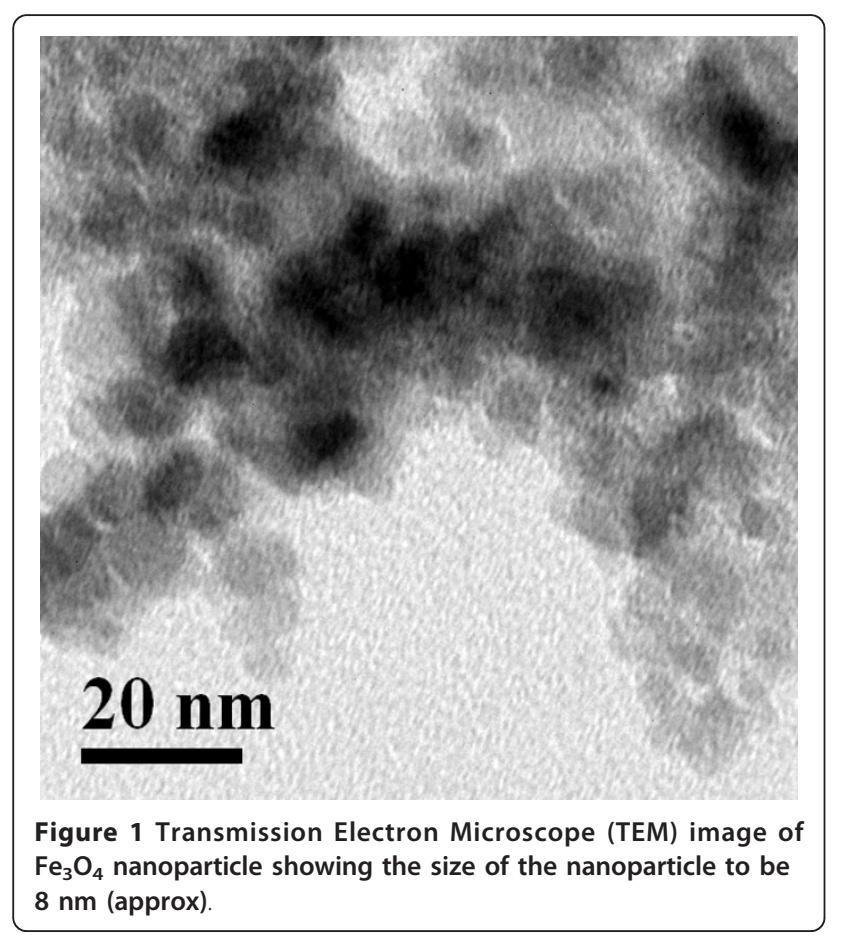

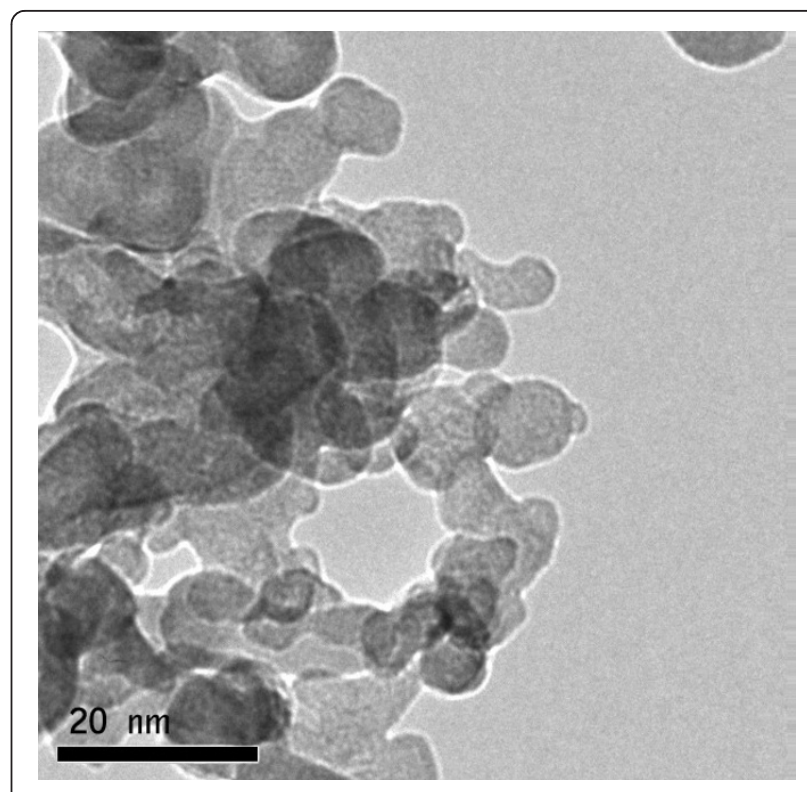

Figure 2 Transmission Electron Microscope (TEM) image of Au nanoparticle showing the size of the nanoparticle to be $5 \mathrm{~nm}$ (approx).

compared to OD600 1.14 (cfu count $1.01 \times 10^{8}$ ) in case of iron oxide $(200 \mu \mathrm{g} / \mathrm{mL})$ treated bacterial cells (Figure 6). The reactive oxygen species (ROS) along with superoxide radicals $\left(\mathrm{O}^{2-}\right)$, hydroxide radical $\left(\mathrm{OH}^{-}\right)$and singlet oxygen $\left({ }_{1} \mathrm{O}^{2}\right)$ generated by the iron oxide nanopaticle is thought to be the reason behind the inhibition [15]. ROS production has been found in diverse range of metal oxide nanoparticles that may result in oxidative stress, inflammation and consequent damage to proteins, membranes and DNA which is one of the primary mechanisms of nanotoxicity.

\section{C) Effect of gold nanoparticle on bacterial growth}

When $E$. coli was treated with various concentrations $(25 \mu \mathrm{g} / \mathrm{mL}, 50 \mu \mathrm{g} / \mathrm{mL}, 75 \mu \mathrm{g} / \mathrm{mL} \& 100 \mu \mathrm{g} / \mathrm{mL})$ of gold nanoparticles no significant difference in the growth curve were obtained as shown in Figure 7. The growth experiment under the influence of gold nanoparticle thus reveals the nontoxic nature of the gold nanoparticle in the bacterial system $(E$. coli). Hence, it can be used for biological applications with least chances of cytotoxicity.

\section{D) Microscopic observation}

The study was further extended at the microscopic level using phase contrast microscope. Both the nanoparticles were found to increase the size of the E. coli cell abruptly. The bacterial cell size under the influence of $\mathrm{Fe}_{3} \mathrm{O}_{4}$ nanoparticle when compared to that of normal $E$. coli cell (considering normal $E$. coli cell length to be 
Size Distribution by Intensity

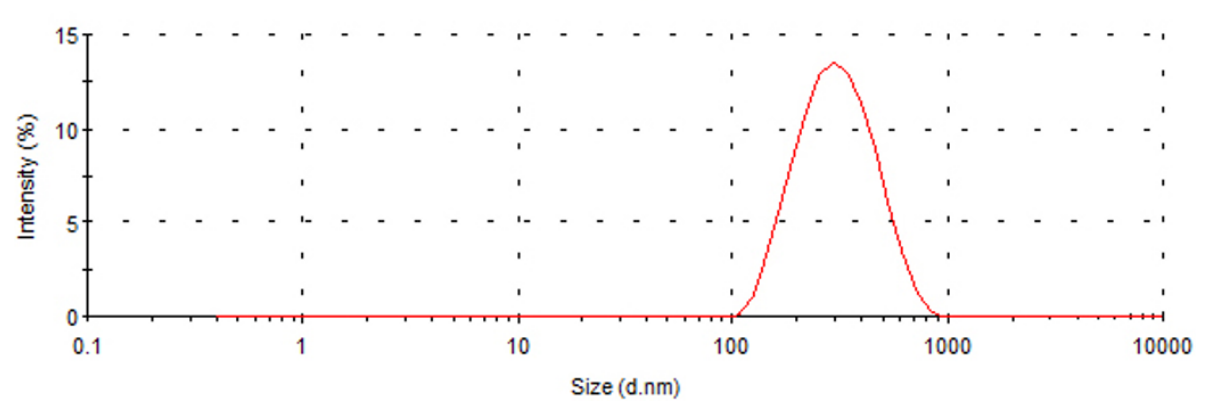

Figure 3 Size distribution intensity graph of $\mathrm{Fe}_{3} \mathrm{O}_{4}$ nanoparticle as revealed by DLS.

approx. $3 \mu \mathrm{m}$ as shown in Figure 8) showed up to a 10 fold increase in size Figure 9. The gold nanoparticle also gave identical result where the increase of cell length was up to 8 fold compared to that of normal $E$. coli cell as shown in Figure 10. The E. coli cells were also found to be clogged in between the iron oxide nanoparticles because of the magnetic property of the nanoparticle and the trapped cells also exhibited increased cell length (Figure 11). Iron oxide nanoparticles due to the high ionic strength frequently agglomerate in environmental and biological fluids, which shield the repulsion due to charges on the nanoparticles. Agglomeration has frequently been ignored in nanotoxicity studies, even though agglomeration would be expected to affect nanotoxicity since it changes the size, surface area, and sedimentation properties of the nanoparticles. Moreover nanoparticles can agglomerate to some extent in the environment or in the body before they reach their target; hence it is also desirable to study how toxicity is affected by agglomeration [16]. Thus our study indicates the effect of both the nanoparticles on the cellular level. Inactivation of certain gene expression required for 'cytokinesis' during cell division may be considered as a probable cause for such effect $[17,18]$. The result clearly shows the involvement of the nanoparticles on the bacterial physiology and is a probable demonstration of DNA nanoparticle interaction. The gold nanoparticle showed high tendency for incorporation within bacterial cells with the least possibility of cytotoxicity. This was evident during microscopic study, where grain like shining spots appeared within the bacterial cells (Figure 12).

\section{E) Biological Application of gold nanoparticle incorporation within bacterial Cells}

As the incorporation of gold nanoparticle on E. coli cells were evident, studies were conducted to use this phenomenon for bio-applications. Since glutathione has an electrostatic interaction with both gold nanoparticle and DNA, the gold nanoparticle was surface modified using glutathione followed by interaction with plasmid DNA. The carboxyl group $\left(\mathrm{COO}^{-}\right)$of glycine residue electrostatically interacts with the positively charged gold nanoparticle to form glutathione functionalized gold nanoparticle. The other free end ( $\gamma$-Glutamine residue) of glutathione now posses an amine group and a carboxyl group among which the amine group nonspecifically interacts with the negatively charged phosphate group of DNA forming a reversible electrostatic complex of gold-glutathione-DNA.

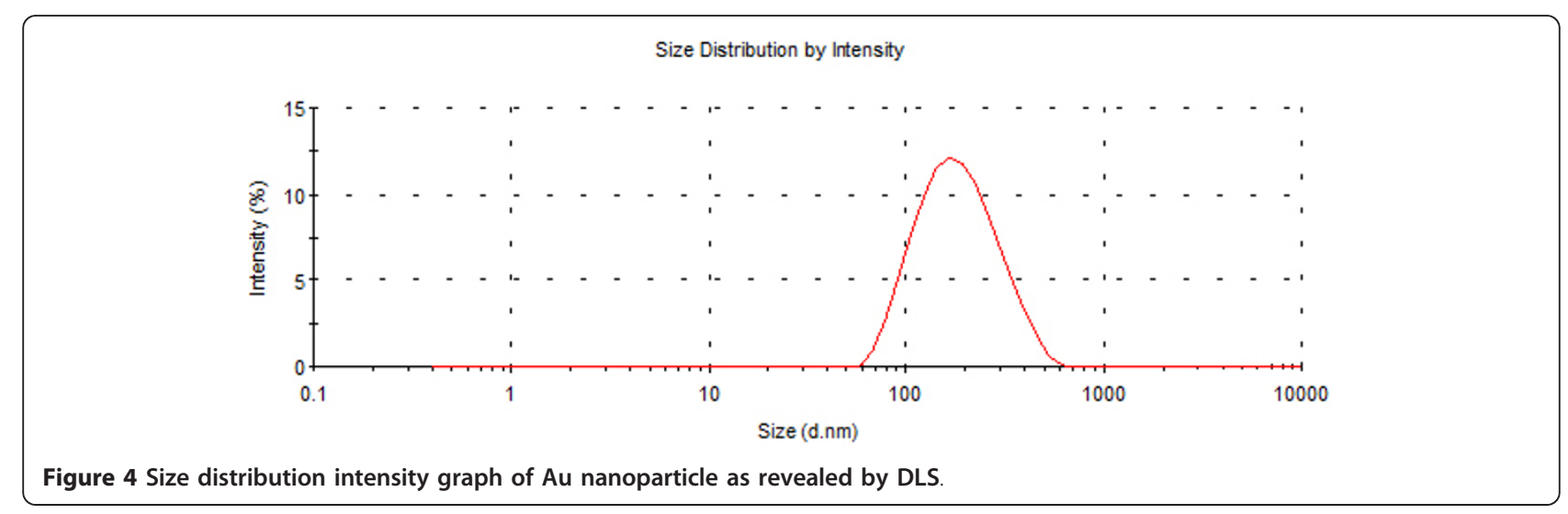



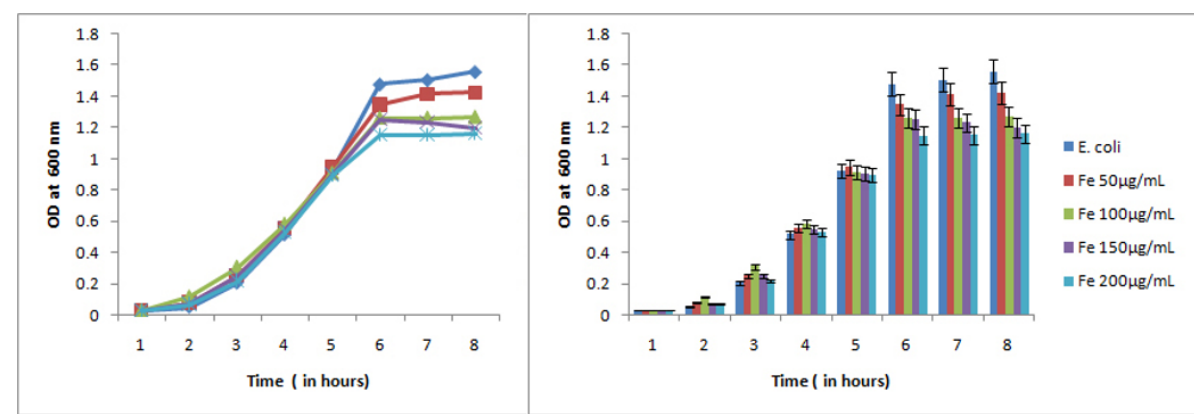

Figure 5 Growth curve of $E$. coli under the influence of $\mathrm{Fe}_{3} \mathrm{O}_{4}$ nanoparticle compared to the normal growth curve of $E$. coli depicting the microbiocidal nature of the $\mathrm{Fe}_{3} \mathrm{O}_{4}$ nanoparticle in a concentration dependant manner.

This complex cleaves when incorporated within the bacterial cell due to ionic variation liberating the intact plasmid DNA from gold-glutathione complex. In our experiment the glutathione surface functionalized gold nanoparticles were used as a vector to insert ampicillin resistant gene (pUC 19) in E. coli that is susceptible to ampicillin. The result showed successful transformation of ampicillin resistant gene in $E$. coli as indicated by the growth of transformed bacteria in appropriate antibiotic containing media. The transformation efficiency was calculated as: Transformation efficiency $=$ (Number of transformed colony/ Amount of DNA in $\mu \mathrm{g}$ ) and was found to be $8.53 \times 10^{5}$ compared to that of $9.55 \times 10^{3}$ using conventional $\mathrm{CaCl}_{2}$ mediated transformation. Thus we report glutathione functionalized gold nanoparticle mediated transformation as a bio-application for which further research is to be carried out to make this process generalized.

\section{Conclusion}

Finally if we consider the recent past age to be of micro scale then the present or near future surely belongs to

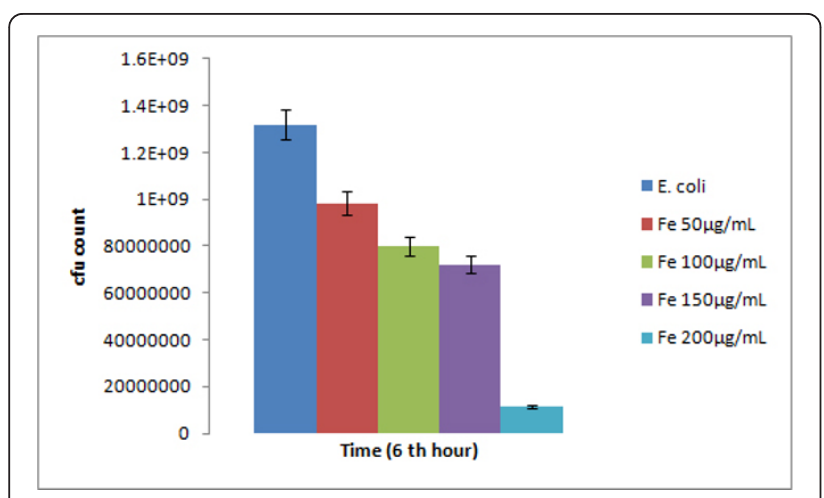

Figure 6 Comparison of colony forming unit (cfu) count of $E$. coli (normal) and under the influence of $\mathrm{Fe}_{3} \mathrm{O}_{4}$ nanoparticle at 6th hour of bacterial growth. nano. Since most of the natural processes also take place in the nanometer scale therefore the association of nanotechnology and biology is expected to solve several biological problems. But the advances of the technology in the nanoscale level also remind the possible negative impact especially at the cellular level. From our research the interaction of two widely used nanoparticles with the bacterial cell was evident which opened a new dimension of biological application in the form of $\mathrm{Au}$ mediated transformation, though further research on the mechanism of interaction can reveal the further consequences which may open up a new domain of study called 'nanotoxicity'. However, as a cautionary note, the results presented are not meant to be generalized beyond the material and biological systems and conditions reported here.

Moreover our study proves the effect can be modified and channelized for human benefit.

Proper knowledge of these interactions can lead to a safe era of nanotechnology without threat of human health risk.

\section{Methods}

\section{A) Preparation of Nanoparticles}

\section{i) Iron (Fe) Nanoparticle}

Magnetic nanoparticles were prepared by chemical coprecipitation of $\mathrm{Fe}^{2+}$ and $\mathrm{Fe}^{3+}$ ions in an alkaline solution and followed by a treatment under hydrothermal conditions [19]. $2.7 \mathrm{~g} \mathrm{FeSO}_{4}, 7 \mathrm{H}_{2} \mathrm{O}$ and $5.7 \mathrm{~g} \mathrm{FeCl}_{3}$ dissolved in $10 \mathrm{~mL}$ nanopure water (double distilled water filtered through $200 \mu \mathrm{m}$ filter) separately. These two solutions was thoroughly mixed and added to double volume $10 \mathrm{M}$ ammonium hydroxide with constant stirring at $25^{\circ} \mathrm{C}$. Then the dark black slurry of $\mathrm{Fe}_{3} \mathrm{O}_{4}$ particles was heated at $80^{\circ} \mathrm{C}$ in a water bath for $30 \mathrm{~min}$. The particles thus obtained exhibited a strong magnetic response. Impurity ions such as chlorides and sulphates were removed by washing the particles several times with nano pure water. Then the particles are dispersed 


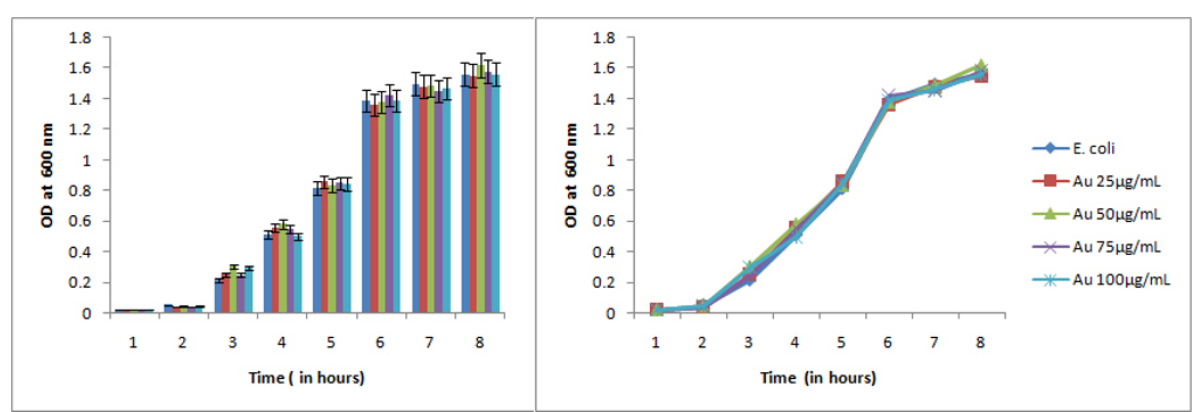

Figure 7 Growth curve of $E$. coli under the influence of Au nanoparticle compared to the normal growth curve of $E$. coli indicating the nontoxic nature of Au nanoparticle.

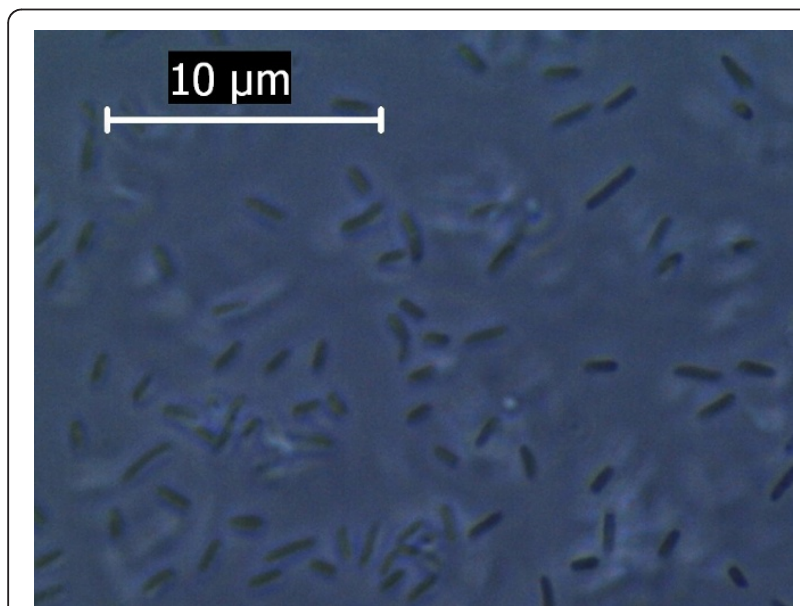

Figure 8 Phase Contrast Microscopic image of E. coli grown under normal condition

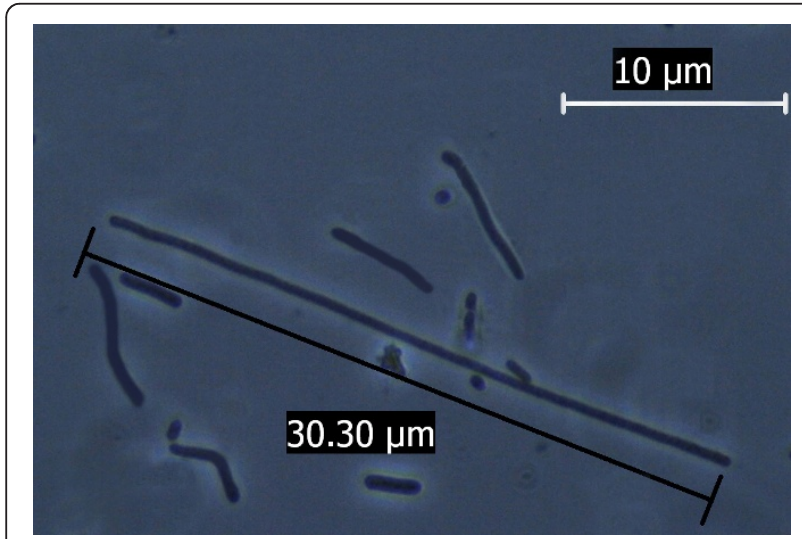

Figure 9 Abrupt increase in $E$. coli cell length (up to 10 fold) grown under the influence of iron oxide nanoparticles, as observed under phase contrast microscope. in $20 \mathrm{~mL}$ nanopure water and sonicated for $10 \mathrm{~min}$ at $60 \mathrm{MHz}$. The yield of precipitated magnetic nanoparticles was determined by removing known aliquots of the suspension and drying to a constant mass in an oven at $60^{\circ} \mathrm{C}$. The prepared magnetic nanoparticles were stable at room temperature $\left(25-30^{\circ} \mathrm{C}\right)$ without getting agglomerated.

\section{ii) Gold (Au) Nanoparticle}

$3 \mathrm{mM} \mathrm{HAuCl}$. solution was directly reduced by $10 \mathrm{mM}$ $\mathrm{NaBH}_{4}$ solution under stirring condition. For further and complete reduction the reaction mixture was reduced again by $10 \mathrm{mg} / \mathrm{ml}$ solution of dextrose. Obtained mixture was subjected to over constant

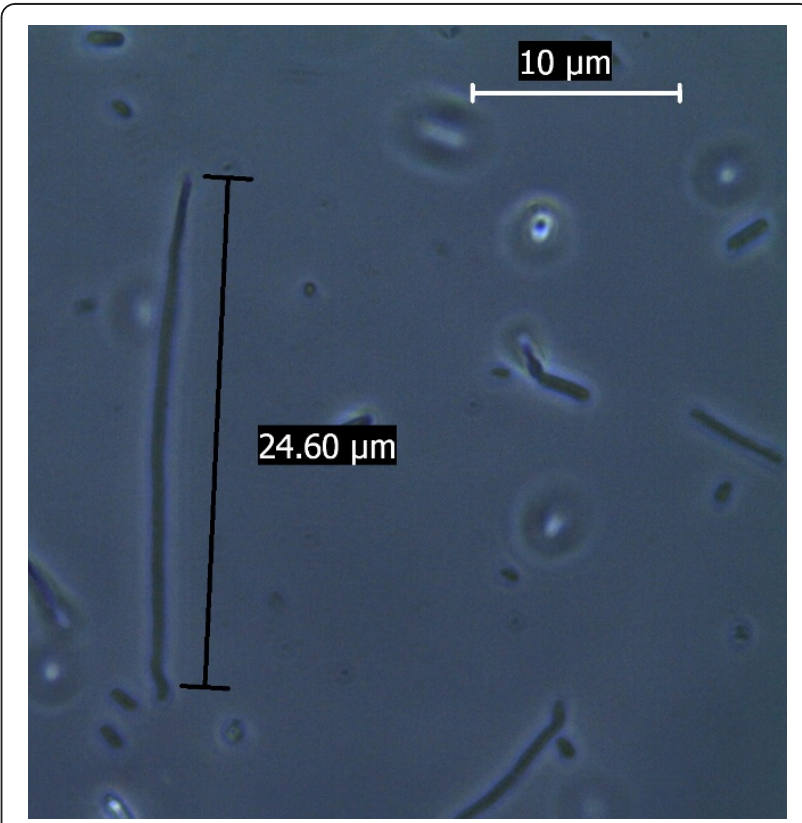

Figure 10 Abrupt increase in $E$. coli cell length (up to 8 fold) grown under the influence of iron oxide nanoparticles, as observed under phase contrast microscope. 


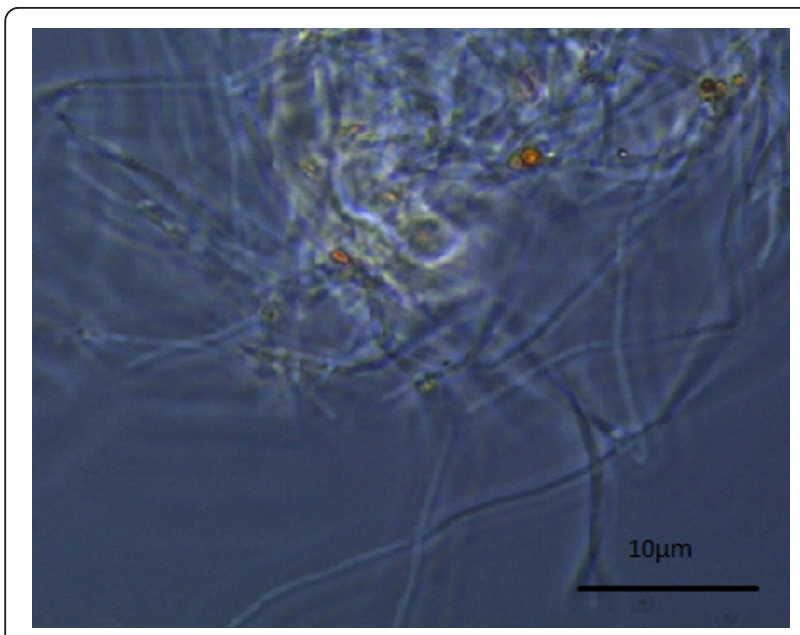

Figure $11 \mathrm{E}$. coli cells with abrupt cell length seen to be clogged in between the iron oxide nanoparticle when viewed under the phase contrast microscope.

stirring. Then the mixture was washed several times with methanol using centrifugation at $65,000 \mathrm{rpm}$.

\section{iii) Glutathione modified Gold (Au) Nanoparticle}

Typically, $3.0 \mathrm{mM}$ of glutathione was dissolved in $40 \mathrm{~mL}$ of distilled water, and $1.0 \mathrm{mM}$ of $\mathrm{HAuCl}_{4}$ was dissolved in $80 \mathrm{~mL}$ of methanol. Mixing the two solutions generates a cloudy, white suspension. Addition of $10 \mathrm{mM}$ of $\mathrm{NaBH}_{4}$ in $10 \mathrm{~mL}$ of water to this stirring suspension results in an immediate color change to dark brown indicating the generation of large cluster compounds. After additional stirring, the solution was evaporated at $43^{\circ} \mathrm{C}$ to near dryness and excess methanol was added to precipitate the clusters and wash reaction byproducts and any remaining starting material. The precipitate was then filtered and redissolved in $10 \mathrm{~mL}$ of distilled water, precipitated again with methanol, and filtered. These steps were repeated until a fine black powder was obtained [20].

\section{B) Growth Experiment}

Test organism Escherichia coli (E. coli) were grown separately in $50 \mathrm{~mL}$ sterilized Luria Bertani (LB) broth medium and kept in shaker incubator at $37^{\circ} \mathrm{C}$ for 14 hour (overnight incubation). On the subsequent day test organism cultures were transferred at the rate of $1 \%$ in $100 \mathrm{~mL} \mathrm{LB}$ broth kept in $250 \mathrm{~mL}$ conical flasks. Various concentrations of nanoparticles $\left(\mathrm{For} \mathrm{Fe}_{3} \mathrm{O}_{4} 50 \mu \mathrm{g} / \mathrm{mL}\right.$ to $200 \mu \mathrm{g} / \mathrm{mL}$ and for $\mathrm{Au} 25 \mu \mathrm{g} / \mathrm{mL}$ to $100 \mu \mathrm{g} / \mathrm{mL}$ ) were carefully placed into each flask, leaving one as a control to track the normal growth of the microbial cells without nanoparticles. Experiments were performed using both a negative control (flask containing cells plus media) and a positive control (flask containing nanoparticles plus media). The flasks were shaken at $180 \mathrm{rpm}$ and $37^{\circ} \mathrm{C}$ in a shaker incubator. Optical density measurements from each flask were taken every one hour to record the growth of the microbes in a spectrophotometer set at $600 \mathrm{~nm}$. The growth rate of microbial cells interacting with the nanoparticles was determined from a plot of the log of the optical density versus time.

\section{C) Microscopic Study}

The microscopic study on the morphology i.e the shape, size of the bacteria and interaction with the inorganic nanoparticles were conducted using Phase contrast microscope (Leica DM 750). $10 \mu \mathrm{L}$ of culture was withdrawn every hour and microscopic study was conducted. The parameters were compared between normal culture and culture under the influence of inorganic nanoparticles $\left(\mathrm{Fe}_{3} \mathrm{O}_{4} \& \mathrm{Au}\right)$.

\section{D) Biological Application of Au Nanoparticle}

As the property of internalization of Au nanoparticle within the E. coli cell was observed, the phenomenon was further investigated for its potential to be used for biological application. The insertion of Ampicillin resistant gene in the form of pUC 19 (Plasmid) was tried

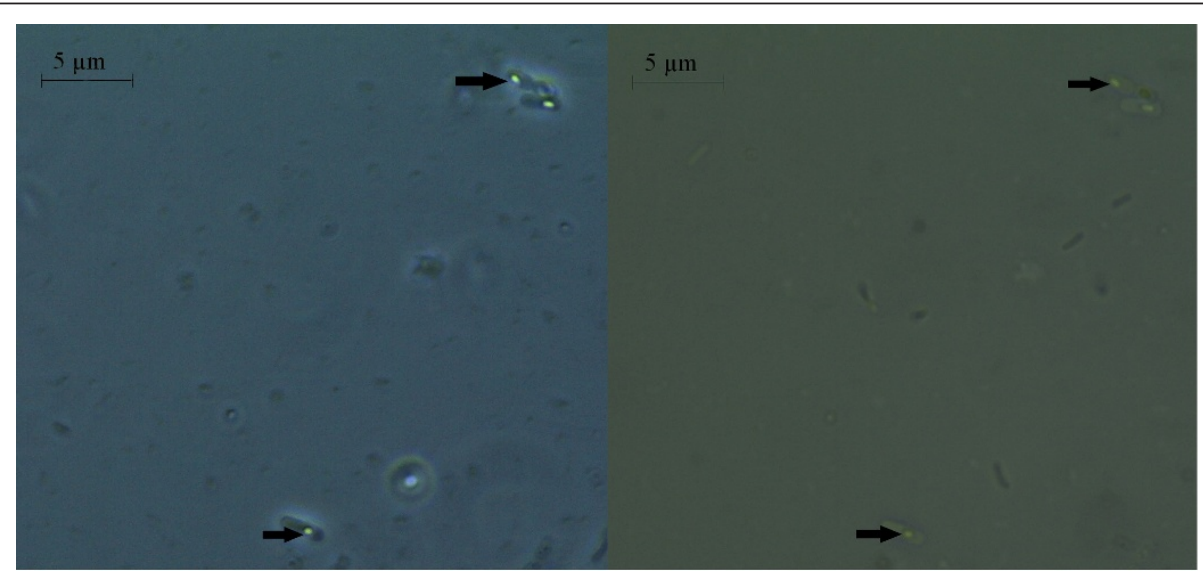

Figure 12 Incorporation of Au nanoparticle was observed in the bacterial cell. 
using the Au nanoparticles as vector/transport machinery. E. coli cells were grown on LB (Luria Bertani) broth till the O.D reaches $0.2 .10 \mu \mathrm{L}$ of Au nanoparticles (50 $\mu \mathrm{g} / \mathrm{mL}$ ) were allowed to interact with $10 \mu \mathrm{L}$ pUC 19 DNA (Bioserve, India) taken from a stock of $0.32 \mathrm{ng} / \mu \mathrm{L}$ for 2 hours at $37^{\circ} \mathrm{C}$. Subsequently $1 \mathrm{~mL}$ of the E. coli culture (0.2 O.D) was centrifuged at 10,000 rcf for 1 min and $20 \mu \mathrm{L}$ of pUC 19-Au nanoparticle mixture was added to the pellet. $980 \mu \mathrm{L}$ of fresh LB medium was also added to it, mixed and incubated at $37^{\circ} \mathrm{C}$ for $5 \mathrm{hrs}$ in shaking condition. Finally $100 \mu \mathrm{L}$ of the culture were withdrawn and plated on Luria Bertani agar medium containing $50 \mu \mathrm{g} / \mathrm{mL}$ of ampicillin. The plates were incubated at $37^{\circ} \mathrm{C}$ overnight and numbers of colonies were counted. The cfu (Colony Forming Unit) count express the number of $E$. coli cells which posses the ampicillin resistant property acquired due to insertion of pUC 19 plasmid. The cfu count for the number of bacterial cells in the initial stage was also noted to compare the number of transformed cell to that of total bacterial cell. This efficiency of this method was also compared to that of conventional method [21] using $\mathrm{CaCl}_{2}$ mediated transfer of plasmid DNA in competent cells.

\section{Authors information}

S. Chatterjee: M.Sc. Microbiology, Research Scholar, University of Kalyani.

A. Bandyopadhyay: M.Sc. Microbiology, Research Scholar, University of Kalyani.

K. Sarkar: M.Sc., PhD, Asst. Professor, Dept. of Microbiology, University of Kalyani.

\section{Acknowledgements}

The research work has been carried out with the financial support of Dept. of Science \& Technology, Govt. of India (Project-Nanomission: SR/NM/ NS-48/2009) and University of Kalyani, Nadia, West Bengal.

\section{Authors' contributions}

SC carried out the growth experiments and biological application part whereas $\mathbf{A B}$ was engaged in the synthesis and characterization of nanoparticles. KS supervised in the design of the study along with critical interpretations while drafting the manuscript. All authors read and approved the final manuscript.

\section{Competing interests}

The authors declare that they have no competing interests.

Received: 30 June 2011 Accepted: 23 August 2011

Published: 23 August 2011

\section{References}

1. Chan WCW, Nie S: Quantum dot bioconjugates for ultrasensitive nonisotopic detection. Science 1998, 281:2016-2018.

2. Chouly C, Pouliquen D, Lucet I, Le Jeune JJ, Jallet P: Development of superparamagnetic nanoparticles for MRl: effect of particle size, charge and surface nature on biodistribution. J Microencapsulation 1996, 13:245-255.
3. Couvreur P, Dubernet C, Puisieux F: Controlled drug delivery with nanoparticles: current possibilites and future trends. Eur J Pharm Biopharm 1994, 41:2-13.

4. Douglas SJ, Davis SS, Illum L: Nanoparticles in Drug Delivery. Crit Rev Ther Drug Carrier Syst 1987, 3:233-261.

5. Pouliquen D, Perroud H, Calza F, Jallet P, Le Jeune JJ: Investigation of magnetic properties of iron oxide nanoparticles used as contrast agent for MRI. Magnetic Resonance in Medicine 1992, 24:75-84.

6. Pinto-Alphandary Andremont HA, Couvreur P: Targeted delivery of antibiotics using liposomes and nanoparticles: research and applications. Int J Antimicrob Agents 2000, 13:155-168.

7. Chertok B, Moffat BA, David AE, Yu F, Bergemann C, Ross BD, Yang VC: Iron oxide nanoparticles as a drug delivery vehicle for MRI monitored magnetic targeting of brain tumors. Biomaterials 2008, 29(4):487-496.

8. Kohler N, Sun C, Wang J, Zhang M: Methotrexate-modified superparamagnetic nanoparticles and their intracellular uptake into human cancer cells. Langmuir 2005, 21(19):8858-8864.

9. Gupta AK, Gupta M: Synthesis and surface engineering of iron oxide nanoparticles for biomedical applications. Biomaterials 2005, 26(18):3995-4021.

10. Berry CC, Curtis ASG: Functionalisation of magnetic nanoparticles for applications in biomedicine. J Phys D Appl Phys 2003, 36:R198-R206.

11. Hirsch $L R$, Halas NJ, West $J \mathrm{~L}$ : Whole-blood immunoassay facilitated by gold nanoshell-conjugate antibodies. Methods Mol Biol 2005, 303:101-11.

12. Gao X, Cui Y, Levenson RM, Chung LWK, Nie S: In vivo cancer targeting and imaging with semiconductor quantum dots. Nat Biotechnol 2004, 22:969-76.

13. Fu G, Vary PS, Lin CT: Anatase TiO2 nanocomposites for antimicrobial coatings. J Phys Chem B 2005, 109:8889-8898.

14. Warheit DB: How meaningful are the results of nanotoxicity studies in the absence adequate material characterization? Toxicol Sci 2008, 101:183-185.

15. Sies H: Oxidative stress: oxidants and antioxidants. Exp Physiol 1997, 82(2):291-295.

16. Zook JM, Maccuspie Rl, Locascio LE, Halter MD, Elliott JT: Stable nanoparticle aggregates/agglomerates of different sizes and the effect of their size on hemolytic cytotoxicity. Nanotoxicology 2010, 1-14, Early online Edition, 13th Dec.

17. Osborn MJ, Rothfield L: Cell shape determination in Escherichia coli. Curr Opin Microbiol 2007, 10(6):606-10.

18. Trun NJ, Gottesman S: On the bacterial cell cycle: Escherichia coli mutants with altered ploidy. Genes Dev 1990, 4:2036-2047.

19. Bandyopadhyay A, Chatterjee S, Sarkar K: Rapid isolation of genomic DNA from E. coli XL1 Blue strain approaching bare magnetic nanoparticles. Current Science 2011, 101(2):210-214.

20. Schaaff TG, Whetten RL: Giant Gold-Glutathione Cluster Compounds: Intense Optical Activity in Metal-Based Transitions. J Phys Chem B 2000, 104:2630-2641.

21. Sambrook J, Russell DW: Preparation and transformation of competent $E$. coli using calcium chloride. In Molecular Cloning: A Laboratory Manual. Volume 1.. 3 edition. New York, Cold Spring Harbor Laboratory Press; 2001:116, Volume 1.

doi:10.1186/1477-3155-9-34

Cite this article as: Chatterjee et al:: Effect of iron oxide and gold nanoparticles on bacterial growth leading towards biological application. Journal of Nanobiotechnology 2011 9:34. 